http://ejournal.undip.ac.id/index.php/kapal

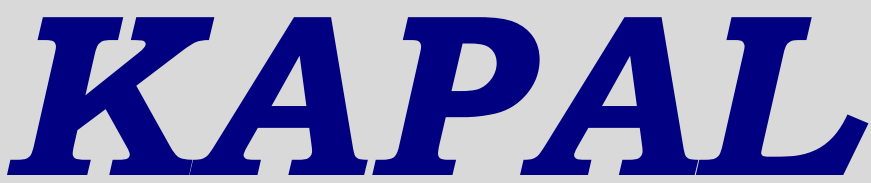

\title{
Pengaruh Susunan dan Ukuran Bilah Bambu Petung (Dendrocalamus asper) Dan Bambu Apus (Gigantochloa apus) Terhadap Kekuatan Tarik, Kekuatan Tekan Dan Kekuatan Lentur Untuk Komponen Konstruksi Kapal
}

\author{
Parlindungan Manik ${ }^{1)}$, Hartono Yudo ${ }^{l)}$, Fredits A Siahaan ${ }^{\left.1)^{*}\right)}$ \\ ${ }^{1)}$ Departemen Teknik Perkapalan, Fakultas Teknik, Universitas Diponegoro \\ Jl. Prof. Soedarto, SH, Kampus Undip Tembalang, Semarang, Indonesia 50275
}

diajukan pada : 08/11/17 direvisi pada : 13/11/17 diterima pada : 16/11/17

\begin{abstract}
Abstrak
Bambu laminasi merupakan bahan bangunan rekayasa yang dibentuk dengan sistem perekatan beberapa bilah bambu sehingga memiliki kelebihan dapat dibuat dalam berbagai ukuran dan sifat mekanika yang lebih uniform dari bahan bambu alami. Teknik laminasi dari bahan bambu menjadi solusi untuk mengembangkan sebuah produk kayu yang memiliki struktur dan sifat mekanik lebih kuat dan awet. Prosedur pembuatan dan pengujian spesimen kayu laminasi bambu petung dan bambu apus mengacu pada SNI-03-3958-1995, SNI-03-3399-1994 dan SNI 03-3959-1995. Penelitian ini bertujuan untuk mendapatkan nilai kuat tarik, kuat tekan dan kuat lentur dari dua jenis variasi susunan bilah horizontal dan bata/carvel dengan tebal bilah $3 \mathrm{~mm}, 5 \mathrm{~mm}$ dan $7 \mathrm{~mm}$. Hasil penelitian pada laminasi bambu petung dan bambu apus diperoleh kadar air 12-13\% dan berat jenis 0,60-0,65 $\mathrm{gr} / \mathrm{cm}^{3}$ memiliki kuat tarik terbesar 96,72 Mpa (kode PA7H), kuat lentur 101,69 MPa (kode PA7B) dan kuat tekan 22,11 MPa (kode PA7B). Variasi susunan bata dan tebal bilah semakin besar mempengaruhi kekuatan tekan dan lentur. Namun sebaliknya untuk kuat tarik, susunan horizontal lebih baik dari susunan bata. Nilai tersebut memenuhi persyaratan kayu lapis sebagai bahan material kapal kayu menurut BKI dan termasuk dalam kelas kuat II sehingga dapat digunakan sebagai material konstruksi kapal.
\end{abstract}

Copyright (C) 2017, KAPAL, 1829-8370 (p), 2301-9069(e)

Kata Kunci : Kayu Laminasi, Kapal Kayu, Kuat Lentur, Kuat Tarik, Kuat Tekan, Variasi Susunan

\section{PENDAHULAN}

Kerusakan hutan di Indonesia saat ini tercatat di Guinnes World Record sebagai perusak hutan tercepat di dunia pada tahun 2008 [1]. Bahkan berdasarkan data - data dari Perserikatan Bangsa - Bangsa (PBB) tahun 2000 hingga 2005 rata rata perhari $51 \mathrm{~km}^{2}$ hutan Indonesia hilang (rusak). Sesuai perhitungan kerusakan hutan Dinas Kebudayaan dan Pariwisata Pemkab Darito Selatan pada tahun 2012, diperkirakan hutan

*) Penulis Korespondensi :

Email : freditssiahaan@yahoo.co.id
Sumatera dan hutan Kalimantan akan punah pada tahun 2022. Hal ini pasti akan berdampak pada pembuatan kapal kayu di Indonesia karena juga sulit mendapatkan bahan baku utama kapal yaitu kayu. Selain itu, dengan keterbatasan jumlah bahan baku kayu juga berpengaruh pada harga kapal kayu yang akan semakin tinggi. Untuk itu, perlu ada pengembangan produk komposit untuk mengatasi kelangkaan bahan baku kayu serta meminimalkan pengeluaran, namun tetap mendapatkan karakterisitik kayu yang kuat dan awet. Salah satu solusinya adalah dengan cara laminasi berbahan bambu. 
Bambu banyak digunakan sebagai bahan baku konstruksi bangunan. Selain untuk konstruksi kapal, kayu dan bambu juga digunakan untuk konstruksi rumah dan jembatan tradisional. Hal ini karena bambu merupakan bahan yang murah dan mudah diperoleh [2].

Bambu Petung banyak tumbuh di daerah tropis, membentuk rumpun kecil berkelompok. Pertumbuhan bambu relatif cepat dan berkembang secara maksimal pada musim penghujan. Proses pengkayuan dicapai pada umur 2-5 tahun, bambu disebut tua atau masak bila berumur 6-7 tahun. Bambu petung banyak dipakai sebagai bahan bangunan, perahu, kursi, dipan, saluran air, penampung air aren hasil endapan, dinding (gedeg), dan berbagai jenis kerajinan. Data kekuatan bambu petung terdapat pada Tabel 1 .

Tabel 1. Data Kekuatan Bambu Petung [3]

\begin{tabular}{llc}
\hline No & Jenis Pengujian & Nilai (MPa) \\
\hline 1 & Kuat Lentur & 134,972 \\
2 & Kuat Tekan Tegak Lurus & 24,185 \\
& Serat & \\
3 & Kuat Tekan Sejajar Serat & 49,206 \\
4 & Kuat Geser & 9,505 \\
5 & Kuat Tarik Sejajar Serat & 228 \\
6 & Modulus Elastisitas Lentur & 12888,477 \\
\hline
\end{tabular}

Untuk sifat mekanis bambu petung yang telah dilaminasi telah diteliti lebih dalam oleh [4] dan referensi [5] meneliti mengenai sifat mekanika bambu laminasi menggunakan bambu guadua.

Bambu Apus atau biasa disebut bambu tali dapat mencapai tinggi hingga 20 meter lebih. Diameter batang antara 2,5 sampai $15 \mathrm{~cm}$, tebal dinding 3 sampai $15 \mathrm{~mm}$.

Bambu apus dalam nilai kadar kering udara $12-15 \%$ memiliki nilai berat jenis $0,59 \mathrm{gr} / \mathrm{cm}^{3}$. Kekuatan lentur 502,3 - 1240,3 kg/ $\mathrm{cm}^{2}$, modulus elastisitas lentur $57.515-121.334 \mathrm{~kg} / \mathrm{cm}^{2}$, keteguhan tarik $1.231-2.859 \mathrm{~kg} / \mathrm{cm}^{2}$.

Di bidang perkapalan, penelitian mengenai laminasi bambu apus dan bambu petung untuk komponen konstruksi kapal telah dikaji mengenai kekuatan tarik dan lenturnya dengan memvariasikan komposisi susunannya [6]. Selain itu, pengaruh suhu kempa terhadap kualitas balok tersebut juga telah diteliti oleh [7]. Sedangkan untuk kajian teknik dan ekonomis terhadap laminasi bambu apus dan petung diteliti oleh [8]. Selainn kombnasi tersebut, kajian teknis dan ekonomis laminasi antara bambu apus dan kayu meranti juga telah dilakukan oleh [9].

Tujuan dari penelitian ini adalah untuk mengetahui dan membandingkan kekuatan lentur, tarik dan tekan varian bilah laminasi, yaitu susunan horizontal dan susunan bata (carvel). Kemudian untuk mendapatkan laminasi bambu dengan nilai yang optimal dengan melakukan uji eksperimental tarik, lentur dan tekan kayu secara langsung di laboratorium. Selain itu penelitian ini bertujuan untuk menentukan kelas kuat acuan bambu laminasi untuk komponen konstruksi kapal.

\section{METODE}

\subsection{Standar Pengujian}

Berikut adalah standar pengujian material yang digunakan pada penelitian ini.
a. Standar pengujian SNI 03-3399-1994 untuk pengujian tarik sejajar serat [10].
b. Standar pengujian SNI 03-3958-1995 untuk pengujian tekan tegak lurus serat [11].
c. Standar pengujian SNI 03-3959-1995 untuk pengujian kuat lentur [12].

\subsection{Parameter Tetap Pengujian}

Pengujian tarik sejajar serat dilakukan menggunakan mesin Universal Testing Machine (UTM). Berikut rincian standar pengujian uji tarik sejajar serat yang akan dilakukan:

- Jumlah spesimen adalah 3 Spesimen/variasi.

- Kecepatan pembebanan // $20 \mathrm{Mpa} /$ menit.

- Ketelitian ukuran penampang $\pm 0,25 \mathrm{~mm}$.

- Ketelitian ukuran panjang benda uji tidak boleh lebih dari $1 \mathrm{~mm}$.

- Bentuk spesimen seperti Gambar 1.

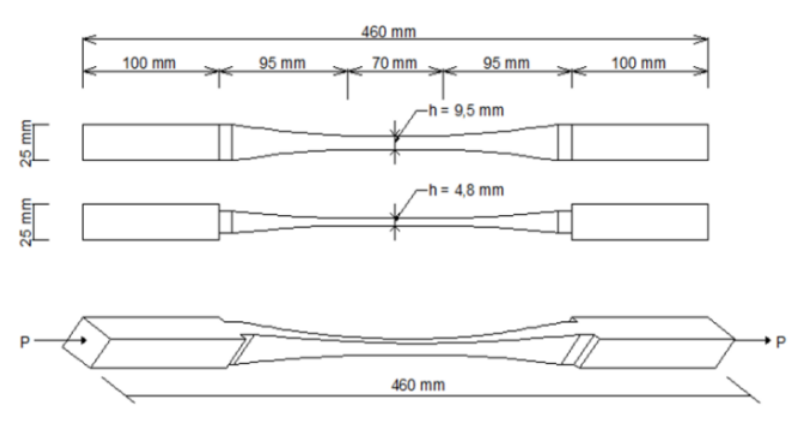

Gambar 1. Bentuk Spesimen Uji Tarik

Persamaan 1 dignakan untuk menghitung nilai kuat tarik sejajar serat.

$$
\sigma_{t r}=\frac{P}{b \times h}
$$


dimana ${ }^{\sigma}{ }_{t r} / /=$ kuat tarik sejajar serat $(\mathrm{MPa}), \mathrm{P}$ adalah beban uji maksimum $(\mathrm{N})$, b adalah lebar daerah uji (mm), h adalah tinggi daerah uji (mm).

Pengujian Tekan tegak lurus serat menggunakan mesin Universal Testing Machine (UTM). Berikut rincian standar pengujian uji tarik sejajar serat yang akan dilakukan:

- Jumlah spesimen adalah 3 spesimen/variasi.

- Kecepatan Pembebanan 0,33mm/menit.

- Ketelitian ukuran penampang $\pm 0,25 \mathrm{~mm}$.

- Ketelitian ukuran panjang benda uji $\leq 1 \mathrm{~mm}$.

- Bentuk spesimen seperti Gambar 2.

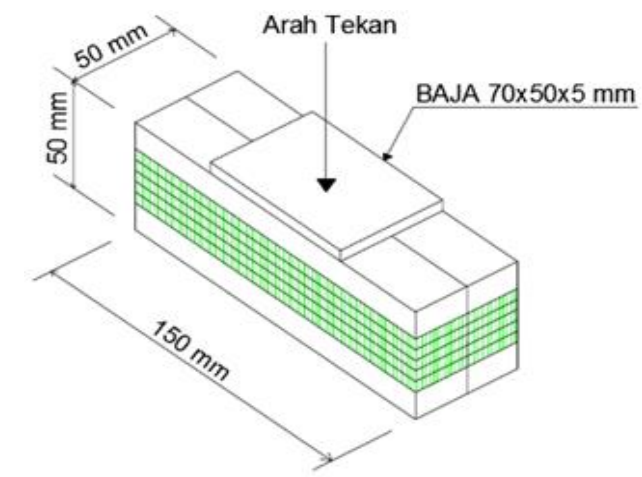

Gambar 2. Bentuk Spesimen Uji Tekan

Persamaan 2 digunakan untuk menhitung nilai kuat tekan tegak lurus serat.

$$
\sigma_{t k}=\frac{P}{b \times h}
$$

dimana: $\sigma_{t k} \perp$ adalah kuat tekan tegak lurus serat (MPa), $\mathrm{P}$ adalah beban uji maksimum $(\mathrm{N}), \mathrm{b}$ adalah lebar daerah uji (mm) dan $\mathrm{h}$ adalah tinggi daerah uji (mm).

Pengujian lentur ini menggunakan ketentuan SNI 03-3959-1995 mengenai metode pengujian kuat lentur kayu di laboratorium. Pengujian dilakukan dengan menggunakan alat Universal Testing Machine (UTM). Perhitungannya menggunakan Persamaan 3 - 4 .

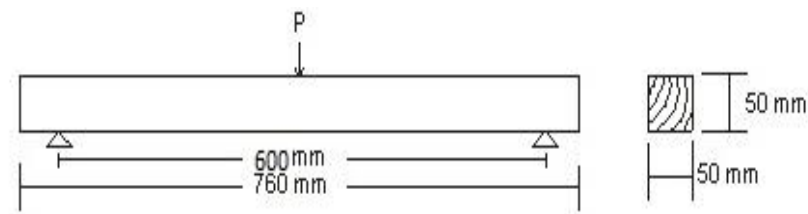

Gambar 3. Bentuk Spesimen Uji Lentur
- Kuat Lentur

$$
f_{b}=\frac{3 P L}{2 b h^{2}}
$$

- Modulus Elastisitas

$$
M O E=\frac{P L^{3}}{4 y b h^{3}}
$$

dimana $\mathrm{f}_{\mathrm{b}}$ adalah kuat lentur (MPa), MOE adalah Modulus of Elasticity (MPa), $\mathrm{P}$ adalah beban gaya $(\mathrm{N}), \mathrm{L}$ adalah panjang tumpuan $(\mathrm{mm}), \mathrm{b}$ adalah lebar spesimen $(\mathrm{mm}), \mathrm{h}$ adalah tebal spesimen $(\mathrm{mm}), \mathrm{y}(\Delta \mathrm{l})$ adalah lendutan/defleksi $(\mathrm{mm})$.

\subsection{Parameter Peubah}

Penelitian ini menggunakan 2 variasi berdasarkan susunan bilah yaitu susunan horizontal dan susunan bata (carvel) dan tebal bilah antara lain $3 \mathrm{~mm}, 5 \mathrm{~mm}$, dan $7 \mathrm{~mm}$. Berikut tabel daftar spesimen mempunyai enam variasi kode uji.

Tabel 2. Daftar Spesimen

\begin{tabular}{cccccc}
\hline \multirow{2}{*}{ No } & \multirow{2}{*}{ Kode } & \multicolumn{2}{c}{ Tebal Bilah } & \multicolumn{2}{c}{ Komposisi } \\
& Uji & Petung & Apus & Petung & Apus \\
\hline 1 & PA3H & $3 \mathrm{~mm}$ & $3 \mathrm{~mm}$ & $50 \%$ & $50 \%$ \\
2 & PA3B & $3 \mathrm{~mm}$ & $3 \mathrm{~mm}$ & $50 \%$ & $50 \%$ \\
3 & PA5H & $5 \mathrm{~mm}$ & $5 \mathrm{~mm}$ & $50 \%$ & $50 \%$ \\
4 & PA5B & $5 \mathrm{~mm}$ & $5 \mathrm{~mm}$ & $50 \%$ & $50 \%$ \\
5 & PA7H & $7 \mathrm{~mm}$ & $5 \mathrm{~mm}$ & $50 \%$ & $50 \%$ \\
6 & PA7B & $7 \mathrm{~mm}$ & $5 \mathrm{~mm}$ & $50 \%$ & $50 \%$ \\
\hline
\end{tabular}

Ket:

$\mathrm{P} \quad=$ Bambu Petung

A $=$ Bambu Apus

3,5,7 = Tebal bilah

$\mathrm{H}=$ Susunan Horizontal

B = Susunan Bata
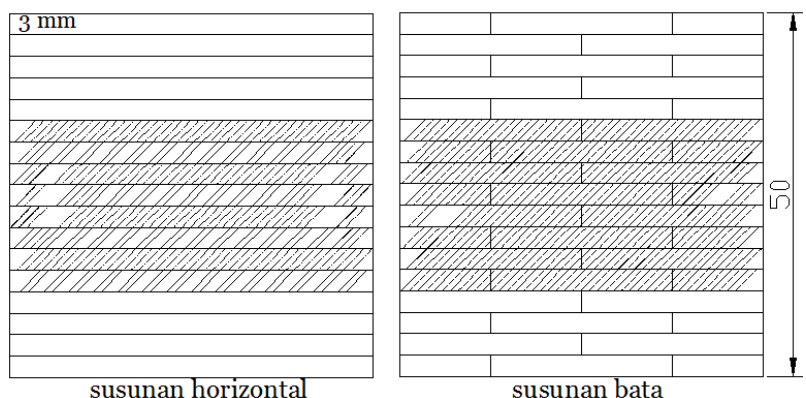

(a) 


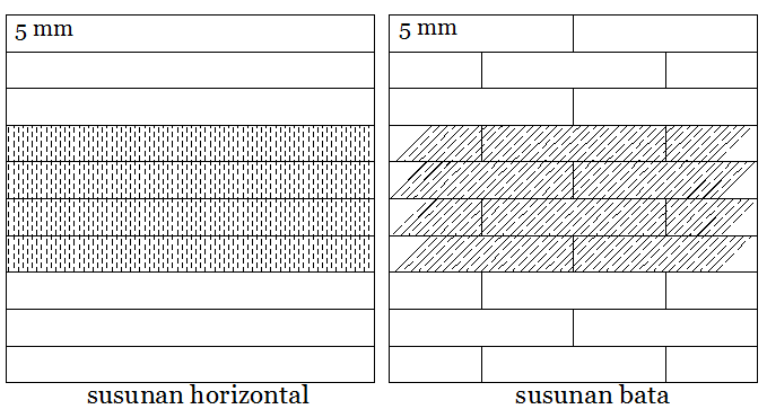

(b)

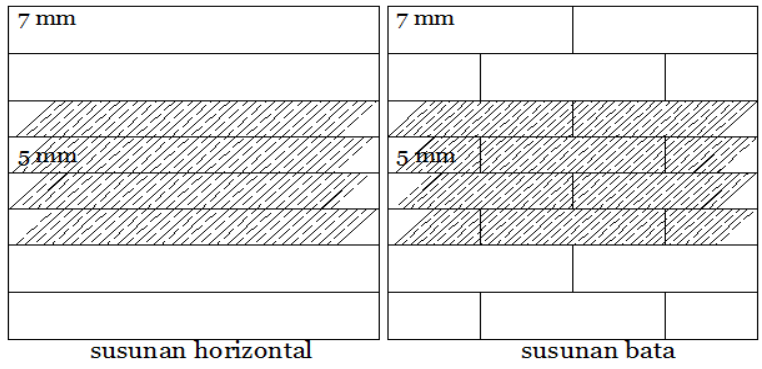

(c)

Gambar 4. Variasi susunan bilah dan tebal bilah (a. $3 \mathrm{~mm}$, b. $5 \mathrm{~mm}$ dan c. $7 \mathrm{~mm}$ )

\subsection{Perekat Laminasi}

Pada penelitian ini, perekat laminasi menggunakan Polyvinyl Acetate (PVAc), dimana perekat tersebut merupakan polimer yang mempunyai sifat kerekatan yang sangat kuat sehingga sering digunakan sebagi bahan dasar pembuatan lem kain, kertas dan kayu. PVAc memiliki sifat tidak berbau, tidak mudah terbakar dan lebih cepat solid.

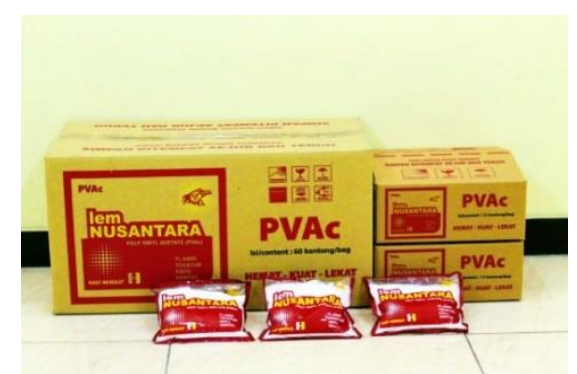

Gambar 5. Polyvinyl Acetate (PVAc)

\section{HASIL DAN PEMBAHASAN}

\subsection{Kadar Air dan Berat Jenis}

Kadar air diperlukan untuk memenuhi standar uji yang terdapat didalam SNI, dimana standar nilai kadar air bahan yang dapat dipakai dalam pengujian harus < 20\% [13]. Selain itu, digunakan untuk memenuhi syarat bahan yang terdapat pada spesifikasi perekat yang digunakan yaitu $<12 \%$. Pada penelitian ini, perhitungan nilai kadar air bahan dilakukan menggunakan Moisture Meter. Hasil dari perhitungan nilai kadar air bambu apus dan bambu petung berada pada $12 \%$ -
13\%. hal ini menunjukan bahwa bahan bambu petung dan bambu apus dalam laminasi telah memenuhi syarat dari standar pengujian SNI dan spesifikasi perekat epoxy.

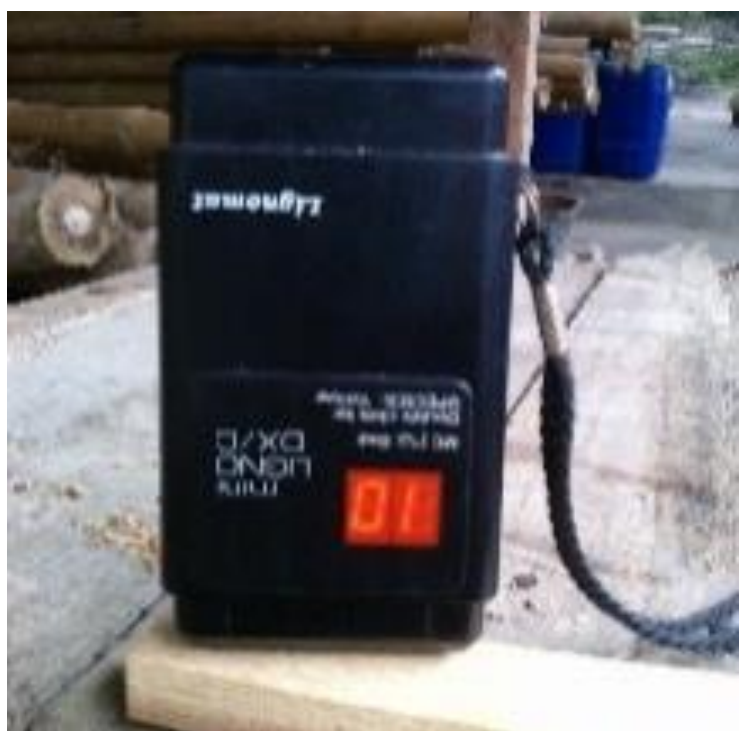

Gambar 6. Pengukuran MC dengan Moisture meter

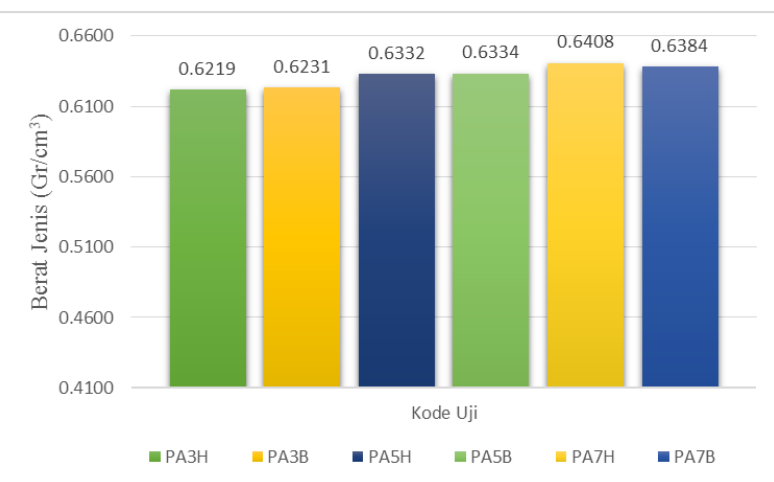

Gambar 7. Perbandingan Berat Jenis Rata-Rata

Dari data yang tertera Gambar 7 dapat kita simpulkan besarnya berat jenis rata-rata tertinggi, yaitu untuk spesimen PA7H. Nilai berat jenis spesimen tersebut sebesar $0,6408 \mathrm{~g} / \mathrm{cm}^{3}$ atau $640,8 \mathrm{~kg} / \mathrm{m}^{3}$ yang tergolong kedalam kelas kuat II.

\subsection{Hasil Uji Lentur}

Spesimen uji lentur terdiri dari 6 variasi. Dari pengujian yang telah dilakukan kita peroleh nilai rata-rata lendutan $(y)$, beban, nilai MOE serta nilai kuat tarik $\left(\mathrm{f}_{\mathrm{b}}\right)$ dari masing-masing variasi dapat dilihat pada Tabel 3 dan Gambar 8.

Tabel 3 dan Gambar 8 menunjukkan bahwa nilai beban maksimal rata-rata pada pengujian lentur terbesar yaitu pada spesimen PA7B (laminasi susunan bata bambu petung - apus dengan tebal bilah $7 \mathrm{~mm}$ ) sebesar 14123,30 N. Pada Gambar 9, spesimen dengan nilai kuat lentur terbesar yaitu PA7B (laminasi susunan bata 
bambu petung - apus dengan tebal bilah $7 \mathrm{~mm}$ ) sebesar 101,69 Mpa.

Pada Gambar 10, nilai lendutan $(\Delta \mathrm{l})$ yang terbesar terjadi pada spesimen $\mathrm{PA} 3 \mathrm{H}$ (laminasi susunan bata bambu petung - apus dengan tebal bilah $3 \mathrm{~mm}$ ) yaitu $12,67 \mathrm{~mm}$.

Pada Gambar 11, spesimen PA7B (laminasi susunan bata bambu petung - apus dengan tebal bilah $7 \mathrm{~mm}$ ) memiliki nilai Modulus of Elasticity (MOE) terbesar yaitu 11781,06 Mpa.

Tabel 3. Data Hasil Pengujian Lentur

\begin{tabular}{ccccc}
\hline Kode & $\begin{array}{c}\text { P Maks. } \\
(\mathbf{N})\end{array}$ & $\begin{array}{c}\Delta \mathbf{l} \\
(\mathbf{m m})\end{array}$ & $\begin{array}{c}\text { MOE } \\
(\mathbf{M p a})\end{array}$ & $\begin{array}{c}\text { MOR } \\
(\mathbf{M p a})\end{array}$ \\
\hline PA3H & 12813.50 & 12.67 & 8752.42 & 92.26 \\
PA3B & 13264.87 & 12 & 9589.08 & 95.51 \\
PA5H & 13358.69 & 11.00 & 10561.35 & 96.18 \\
PA5B & 13753.46 & 10.87 & 10977.98 & 99.02 \\
PA7H & 13799.43 & 10.67 & 11264.07 & 99.36 \\
PA7B & 14123.30 & 10.4 & 11781.06 & 101.69 \\
\hline
\end{tabular}

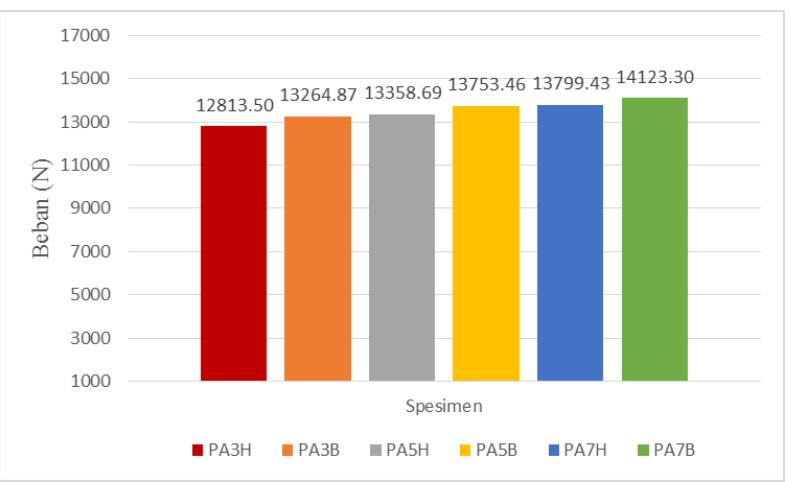

Gambar 8. Perbandingan Beban Lentur

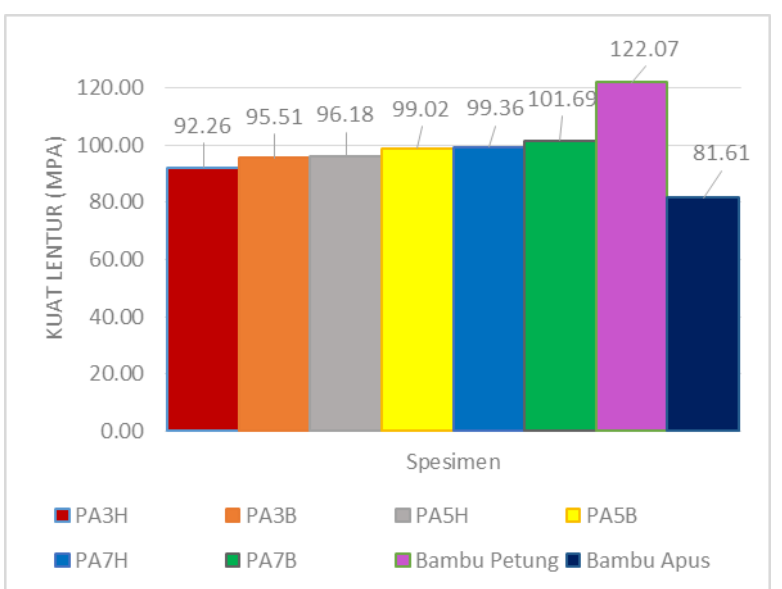

Gambar 9. Perbandingan Kuat Lentur

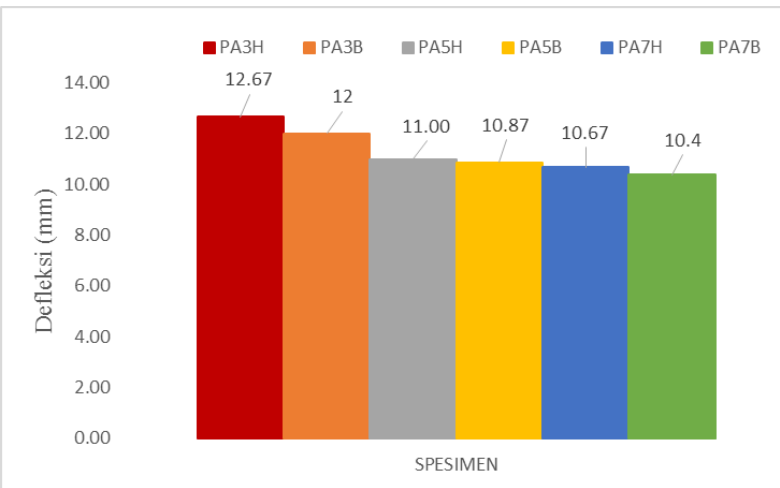

Gambar 10. Perbandingan Besar Lendutan

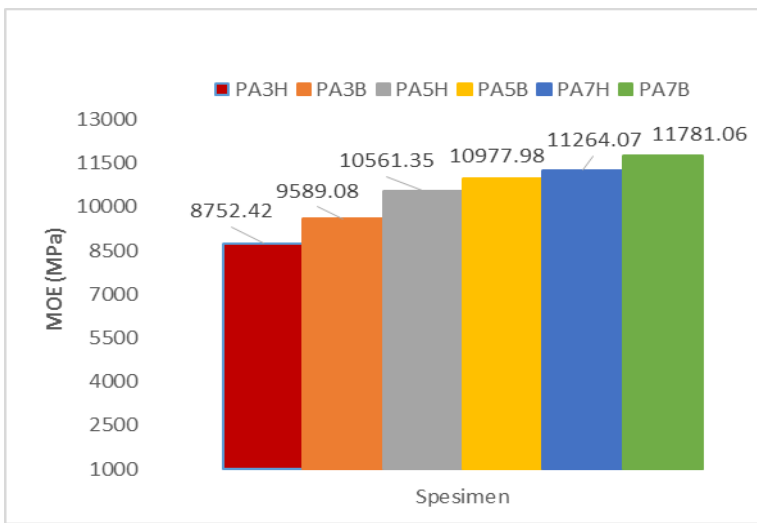

Gambar 11. Perbandingan Modulus of Elasticity

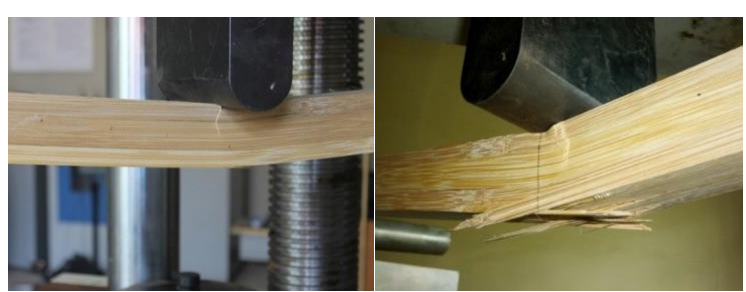

Gambar 12. Proses Pengujian Lentur

\subsection{Hasil Uji Tarik}

Spesimen uji Tarik terdiri dari 6 variasi. Dari pengujian yang telah dilakukan, diperoleh nilai beban, kuat tarik $(\sigma \mathrm{tr} / /)$ serta modulus young (E), sebagai berikut:

Tabel 4. Data Hasil Pengujian Tarik

\begin{tabular}{ccccc}
\hline Kode & $\begin{array}{c}\text { P Maks. } \\
(\mathrm{N})\end{array}$ & $\begin{array}{c}\text { Kuat } \\
\text { Tarik } \\
(\mathrm{Mpa})\end{array}$ & $\varepsilon$ & $\begin{array}{c}\text { Mod. } \\
\text { Young } \\
(\mathrm{MPa})\end{array}$ \\
\hline PA3H & 22677.57 & 90.71 & 0.02133 & 4253.77 \\
PA3B & 22292.45 & 89.17 & 0.02150 & 4149.07 \\
PA5H & 23342.62 & 93.37 & 0.02170 & 4303.43 \\
PA5B & 23149.71 & 92.60 & 0.02130 & 4347.71 \\
PA7H & 24179.99 & 96.72 & 0.02167 & 4465.92 \\
PA7B & 24130.91 & 96.52 & 0.02147 & 4507.24 \\
\hline
\end{tabular}

Pada Tabel 4 dan Gambar 13, dapat dilihat bahwa pembebanan maksimal rata-rata terbesar terjadi pada spesimen PA7H (dengan susunan 
horizontal dan tebal bilah $7 \mathrm{~mm}$ ), yaitu sebesar $24179,99 \mathrm{~N}$.

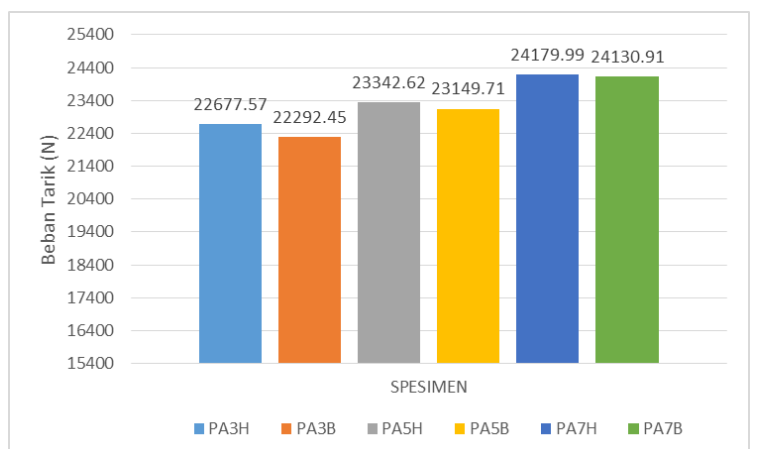

Gambar 13. Perbandingan Beban Tarik

Pada gambar 14, nilai kuat tarik rata-rata terbesar yaitu pada PA7H (dengan susunan horizontal dan tebal bilah $7 \mathrm{~mm}$ ) sebesar 96,72 Mpa. Pada gambar 15, nilai regangan (ع) yang terbesar terjadi pada spesimen PA5H (dengan susunan horizontal dan tebal bilah $5 \mathrm{~mm}$ ) yaitu 0,02170. Pada gambar 16 spesimen PA7B (dengan susunan bata dan tebal bilah $7 \mathrm{~mm}$ ) memiliki nilai modulus young terbesar yaitu 4507,24 Mpa.

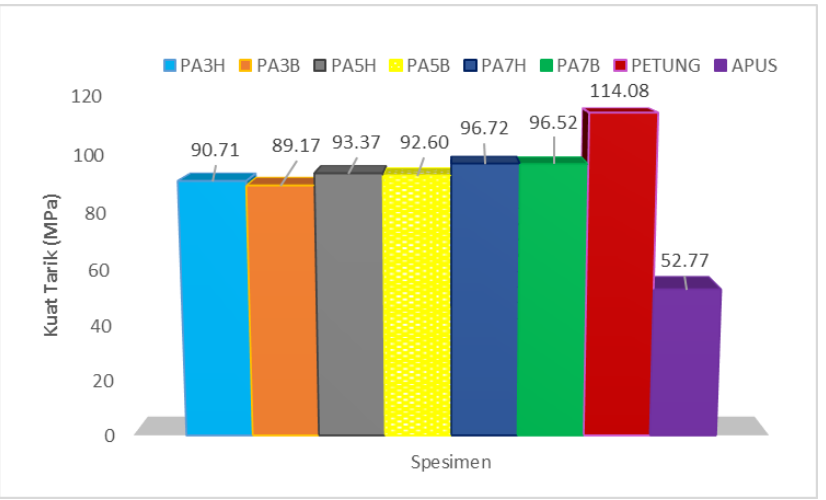

Gambar 14. Perbandingan Kuat Tarik

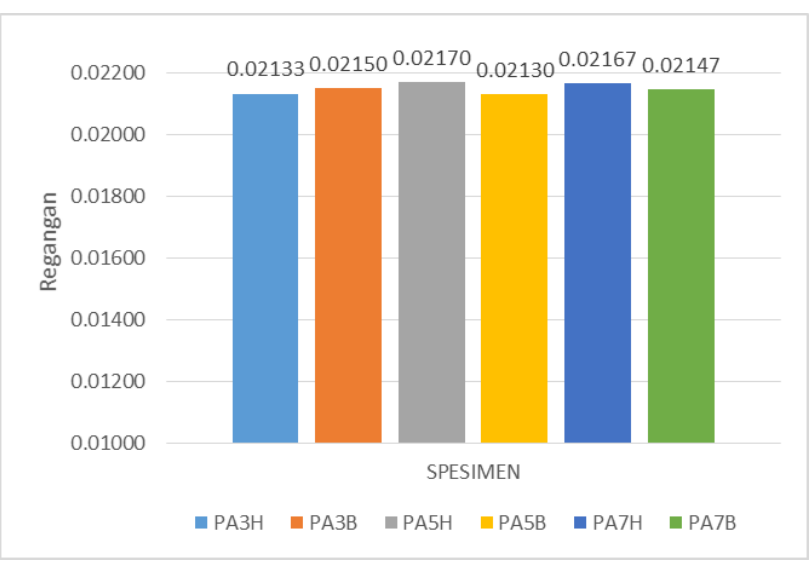

Gambar 15. Perbandingan Besar Regangan

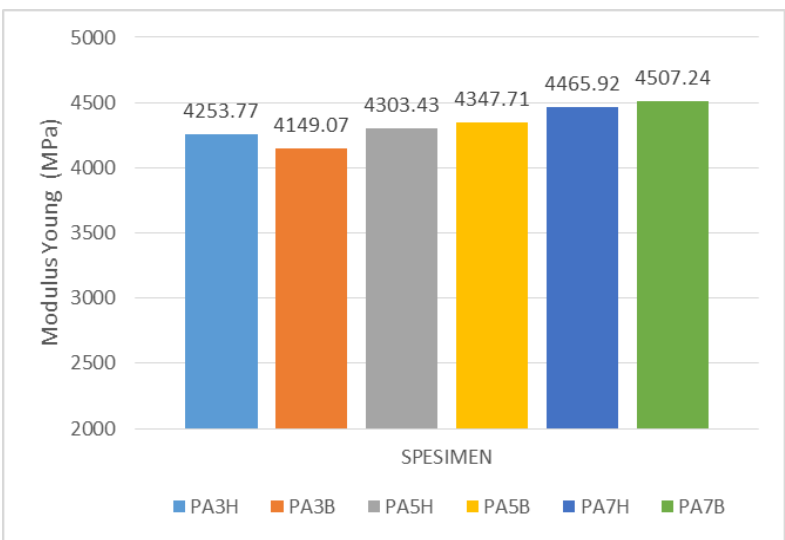

Gambar 16. Perbandingan Modulus Young

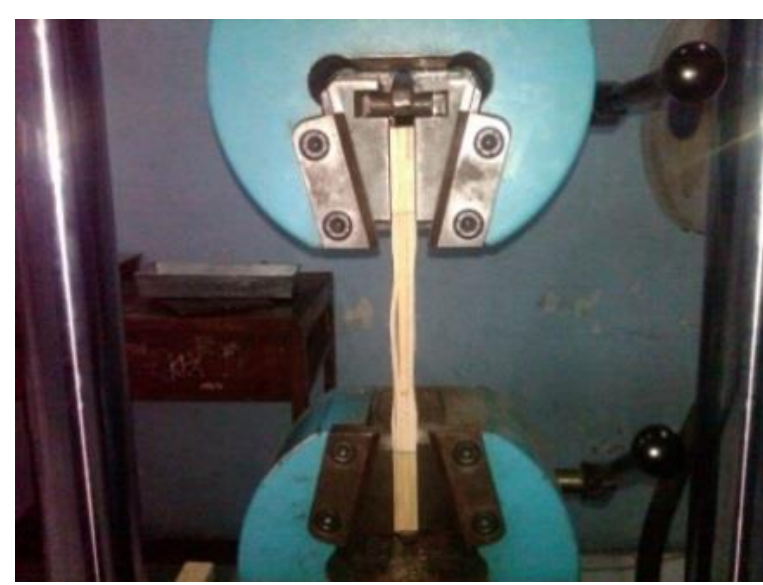

Gambar 17. Proses Pengujian Tarik

\subsection{Hasil Uji Kuat Tekan}

Pada Tabel 5, hasil pengujian yang telah dilakukan, diperoleh nilai beban, kuat tekan ( $\sigma \mathrm{tk} / /$ ) yang terdapat pada Tabel 5 dan Gambar 18. Pada tersebut dapat dilihat bahwa nilai kuat tekan rata-rata terbesar terjadi pada spesimen PA7B (dengan susunan bata dan tebal bilah $7 \mathrm{~mm}$ ), yaitu sebesar $22,11 \mathrm{~N}$.

Tabel 5. Data Hasil Pengujian Kuat Tekan

\begin{tabular}{ccc}
\hline No & Bahan & $\begin{array}{c}\text { Nilai Kuat } \\
\text { Tekan }\end{array}$ \\
\hline 1 & Bambu Petung & 24,23 \\
2 & Bambu Apus & 19,3 \\
3 & PA3H & 20,01 \\
4 & PA3B & 20,44 \\
5 & PA5H & 20,94 \\
6 & PA5B & 21,36 \\
7 & PA7H & 21,91 \\
8 & PA7B & 22,11 \\
\hline
\end{tabular}




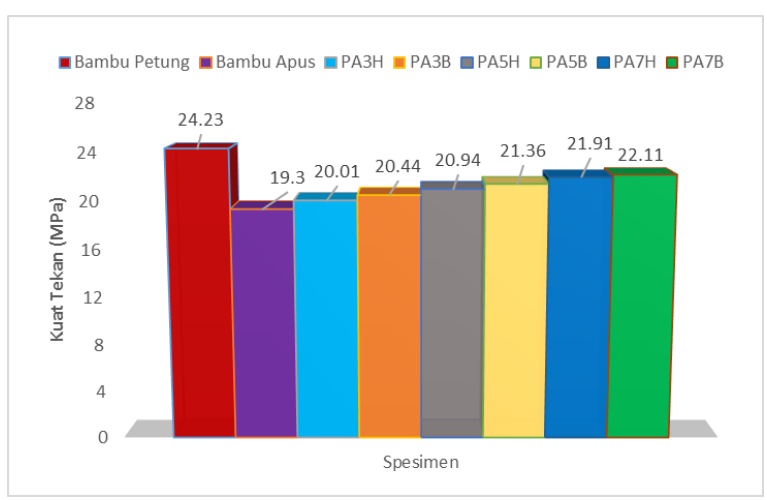

Gambar 18. Perbandingan Kuat Tekan

\subsection{Kelas Kayu Berdasarkan Standar BKI}

Menurut [14] dijelaskan bahwa untuk konstruksi yang penting dalam kapal kayu harus menggunakan kayu dengan mutu minimum Kelas Kuat III Dan Kelas Awet III. Dan untuk kayu lapis harus direkat dengan lem yang disetujui, tahan air serta telah diuji dan distempel oleh BKI, atau dibuat sesuai standar yang diakui dan harus mempunyai kuat tarik minimum $430 \mathrm{~kg} / \mathrm{cm}^{2}$ pada arah memanjang dan $320 \mathrm{~kg} / \mathrm{cm}^{2}$ pada arah melintang.

Tabel 6. Kelas Kuat Kayu [14]

\begin{tabular}{cccc}
\hline $\begin{array}{c}\text { Kelas } \\
\text { Kuat }\end{array}$ & $\begin{array}{c}\text { Berat Jenis } \\
\text { Kering } \\
\text { Udara } \\
\left(\mathbf{g r} / \mathbf{c m}^{\mathbf{3}}\right)\end{array}$ & $\begin{array}{c}\text { Kukuh } \\
\text { Lentur }\end{array}$ & $\begin{array}{c}\text { Kukuh } \\
\text { Tekan } \\
\text { Kg/m }\end{array}$ \\
\hline I & $\geq 0,90$ & $\geq 1100$ & $\geq 650$ \\
II & $0,60-0,90$ & $725-1100$ & $425-650$ \\
III & $0,40-0,60$ & $500-725$ & $300-425$ \\
IV & $0,30-0,40$ & $360-500$ & $215-300$ \\
V & $\leq 0,30$ & $\leq 360$ & $\leq 215$ \\
\hline
\end{tabular}

Berdasarkan hasil pengujian balok laminasi bambu petung dan apus, dengan besar kuat lentur minimal 92,26 $\mathrm{MPa}$ atau setara dengan 940,41 $\mathrm{Kgf} / \mathrm{cm}^{2}$ dan kuat lentur maksimal 101,69 $\mathrm{MPa}$ atau setara dengan 1036,53 Kgf/ $\mathrm{cm}^{2}$. Berdasarkan tabel 6 tentang kelas kuat kayu, menunjukkan bahwa laminasi ini masuk kedalam kelas kuat II.

Hasil pengujian untuk uji tekan laminasi bambu petung dan apus didapatkan nilai kuat tekan rata-rata antara 20,01 MPa sampai 22,11 MPa atau dapat dikonversikan menjadi 203,96 $\mathrm{kg} / \mathrm{cm}^{2}$ sampai $428,04 \mathrm{~kg} / \mathrm{cm}^{2}$. Berdasarkan tabel 6 tentang kelas kuat kayu, menunjukkan bahwa laminasi bambu dan apus masuk dalam kategori Kelas Kuat II.

Hasil pengujian untuk uji tarik laminasi bambu petung dan apus didapatkan nilai kuat tarik rata-rata antara $90,71 \mathrm{MPa}$ sampai 96,72 MPa atau dapat dikonversikan menjadi 924,61 $\mathrm{kg} / \mathrm{cm}^{2}$ sampai $985,87 \mathrm{~kg} / \mathrm{cm}^{2}$. Berdasarkan BKI tentang klasifikasi kayu menunjukkan bahwa laminasi bambu dan apus memenuhi syarat.

Tabel 7. Rekomendasi Penggunaan Bambu Laminasi

\begin{tabular}{ccc}
\hline $\begin{array}{c}\text { Konstruksi } \\
\text { Kapal }\end{array}$ & $\begin{array}{c}\text { Kelas } \\
\text { Kuat }\end{array}$ & $\begin{array}{c}\text { Berat } \\
\text { Jenis }\end{array}$ \\
\hline Gading & V & - \\
Galar Balok & V & V \\
Galar Bilga & V & V \\
Kulit & V & V \\
Geladak & V & V \\
Senta & V & - \\
Lunas & - & - \\
Balok Geladak & V & V \\
Balok Buritan & V & - \\
Linggi & V & - \\
Dudukan Mesin & - & V \\
Lutut Balok & V & V \\
Penumpu Geladak & V & V \\
Papan Geladak & V & V \\
Konstruksi Diatas garis air & V & V \\
\hline
\end{tabular}

Tabel 7 menunjukkan bahwa kayu laminasi bambu petung dan apus memenuhi syarat untuk digunakan sebagai material beberapa bagian kapal.

\section{KESIMPULAN}

Jenis bambu sangat mempengaruhi kekuatan laminasi bambu petung dan apus, hal ini disebabkan nilai kuat tekan, lentur dan tarik bambu petung lebih tinggi dibanding bambu apus.

Semakin besar tebal bilah maka semakin besar nilai kuat laminasi. Hal ini dipengaruhi faktor lem perekat dimana spesimen dengan tebal bilah besar akan membutuhkan lem perekat yang sedikit dibanding dengan tebal bilah yang kecil dan tingkat homogenitasnya suatu spesimen juga semakin lemah apabila membutuhkan lem yang banyak.

Pada uji lentur dan tekan, susunan bata lebih baik dibanding susunan horizontal. Namun pada uji tarik, susunan bilah horizontal lebih baik dari bata. Dari pengujian yang dilakukan rata-rata kuat tarik sejajar terbesar, yaitu pada spesimen laminasi petung-apus susunan horizontal dengan tebal bilah $7 \mathrm{~mm}$ (PA7H) dengan nilai kuat tarik sebesar 96,72 $\mathrm{MPa}$ dengan nilai regangan 0,022 dan modulus young sebesar 4465,92 MPa.

Dari hasil penelitian ini nilai kukuh tekan dan lentur mutlak bambu laminasi menurut BKI tentang klasifikasi kayu termasuk golongan Kelas Kuat II sebagai material konstruksi kapal dan direkomendasikan menggunakan laminasi susunan bata. 


\section{DAFTAR PUSTAKA}

[1] M. Frings, Peran Indonesia Dalam Kebijakan Iklim Internasional Insentif Finansial Untuk Melindungi Kelangsungan Hutan, Jakarta: Yayasan Konrad Adenauer, 2013.

[2] Morisco, Rekayasa Bambu, Yogyakarta: Nafiri Offset, 1999.

[3] I. Irawati dan A. Saputra, "Analisis Statistik Sifat Mekanika Bambu Petung," dalam Prosiding Simposium Nasional Rekayasa dan Budidaya Bambu I, Yogyakarta, 2012.

[4] N. Setyo. H, I. Satyarno, D. Sulistyo dan T. Prayitno, "Sifat Mekanika Bambu Petung Laminasi," Dinamika Rekayasa, vol. 10, no. 1, pp. 6-13, 2014.

[5] J. Correal dan L. Lopez, "Mechanical Properties of Colombian Glued Laminated Bamboo," dalam Modern Bamboo Structures, London, Taylor \& Francis Group, 2008, pp. 121-127.

[6] P. Manik, Samuel dan D. A. Prasetyo, "Analisa Kekuatan Tarik Dan Kekuatan Lentur Balok Laminasi Kombinasi Bambu Petung Dan Bambu Apus Untuk Komponen Kapal Kayu," Kapal, vol. 13, no. 3, pp. 142151, 2016.

[7] P. Manik, S. Jokosisworo dan G. Sadewo, "Pengaruh Suhu Kempa Terhadap Kualitas Balok Laminasi Kombinasi Bambu Petung Dengan Bambu Apus Untuk Komponen Kapal," Kapal, vol. 14, no. 1, pp. 26-32, 2017.

[8] Kamal, P. Manik dan Samuel, "Analisa Teknis Dan Ekonomis Penggunaan Bambu Laminasi Apus Dan Petung Sebagai Material Alternatif Pembuatan Komponen Kapal Kayu," Jurnal Teknik Perkapalan, vol. 5, no. 2, pp. 381-386, 2017.

[9] M. Permana, P. Manik dan B. Adietya, "Analisa Teknis Dan Ekonomis Penggunaan Laminasi Dari Kombinsi Bambu Apus Dan Kayu Meranti Sebagai Material Alternatif Pembuatan Komponen Kapal Kayu," Jurnal Teknik Perkapalan, vol. 5, no. 2, pp. 374380, 2017.
[10] S.N.I, "Metode Pengujian Kuat Tarik Kayu di Laboratorium," Badan Standardisasi Nasional, 1994.

[11] S.N.I, "Metode Pengujian Kuat Tekan di Laboratotium," Badan Standardisasi Nasional, 1995.

[12] S.N.I, "Metode Pengujian Kuat Lentur Kayu di Laboraturium," Badan Standardisasi Nasional, 1995.

[13] A. Widodo, "Pengembangan Komposit Kayu dan Bambu Sebagai Material Alternatif Untuk Pembangunan Kapal Kayu," dalam Prosiding Pertemuan Ilmiah Ilmu Pengetahuan dan Teknologi Bahan, Serpong, 2004.

[14] B.K.I, Volume VI. Peraturan Kapal Kayu, Jakarta: Biro Klasifikasi Indonesia, 1996. 